\title{
Preparation of Potato Whole Flour and Its Effects on Quality of Flour Products: A Review
}

\section{CUI Lingling, TIAN Yange, TIAN Shuangqi*, WANG Yanbo, GAO Fuqiang}

\author{
College of Food Science and Engineering, Henan Uiversity of Technology, Zhengzhou 450001, China
}

\begin{abstract}
When harvested the potato has a high moisture content, this could make its transportation and storage difficult. To help solve the transportation difficulties, potato is made into whole flour by many food processing companies. Potato whole flour has high nutritional value and may be regarded as beneficial to human health and fitness. In addition to the direct use of potato whole flour, it can also be used as added ingredients into other food products. This study summarizes and analyzes the processing technology of potato whole flour and its application in noodle products.
\end{abstract}

Keywords: Potato whole flour; Preparation; Product and process; Flour quality

\section{Introduction}

Potato (Solanum tuberosum L.) is a generic name that contains many well-known or unknown varieties. In daily production and life, the most common varieties are mealy potato, waxy potato and soggy potato. In China, besides high yield and wide planting area, potatoes have many advantages such as tenacious vitality, great adaptability to the environment and multiple nutrition value. Due to the regional culture and different customs, the potato is not a main meal product in many regions. Potatoes are widely planted around the world, with an output of 374 million tons globally each year ${ }^{[1]}$, of which China's output accounts for the largest proportion. Peru was the first country to cultivate potato, that dates back from 8000 to 5000 BC, while China only has 460 years' potato planting history. The potato is not only called one of top four products of the world together with wheat, rice and corn, but also one of the five major crops in the world. Potato whole flour contains large amounts of carbohydrates that can provide energy for people's normal activities. In addition to providing energy, as a multi-functional product $^{[2-3]}$, the potato has many other effects. The Chinese Dietary Guidelines made a professional analysis of the daily diet of people. In the version 2016, each people needs 250 to $400 \mathrm{~g}$ cereals and 50 to $100 \mathrm{~g}$ of tuber crops whole flour every day, which marks the potato to become a main food. Fresh potatoes are not conducive to long-term storage and are perishable during transportation. If fresh potatoes are dehydrated and made to flour, the above problems would be solved effectively. In addition, the supply time will be longer and without seasonal restrictions, which will promote the process of potatoes becoming a staple food in China. Potato flour is an excellent food raw material and food additive that can be applied in cakes, puffed food,

Received: 19 March 2018 /Accepted: 9 April 2018.

Supported by National Key R\&D Program of China (2016YFD0401302), and National Natural Science Foundation of China (31701636).

*Corresponding author. E-mail: tianshuangqi@haut.edu.cn

CHenan University of Technology 2018

CUI L L, TIAN Y G, TIAN S Q, et al. Preparation of Potato Whole Flour and Its Effects on Quality of Flour Products: A Review[J]. Grain \& Oil Science and Technology, 2018, 1(3): 145-150. breakfast food, baby food, condiments and soup ${ }^{[4]}$. In recent years, much attention has been paid to the process and application of potato flour in developed countries, while considerable human and material resources have also been devoted to this kind of research by developing countries ${ }^{[5]}$.

\section{Preparations of Potato Flour}

Fresh potatoes are the raw materials of potato flour. Due to different processing technologies, potato flour is divided into two categories, one is potato granules, which exist as a single particle or in the presence of several cell aggregates; the other is potato flakes that exists as pieces and crumbs. Currently, most of the preparation technologies used in industry are the drying method, backfill method and freeze-melt method ${ }^{[6-9]}$. The backfill method and freeze-thaw method are usually used in making potato granules, the drying method is mainly used in making potato flakes.

\subsection{Drying Method Used in Preparations of Potato Flakes}

The main product of potato flour processing is potato flakes made by drum ${ }^{[10]}$. As shown in Fig. 1, the drying method is widely used in production due to its simple operation and large production.

The experimental data shows that the most suitable conditions for preparations of potato flakes by spray drying is as follows: air temperature is $195^{\circ} \mathrm{C}$, feed flow rate is $9 \mathrm{~mL} / \mathrm{min}$, air flow rate is $0.001715 / \mathrm{s}^{[11]}$, optimum conditions for drum drying is air temperature $145^{\circ} \mathrm{C}$, speed $0.35 \mathrm{~m} / \mathrm{s}_{\text {rotation }}{ }^{[12-14]}$.

\subsection{Backfill Method Used in Preparations of Potato Granules}

As shown in Fig. 2, the backfill method differs from other methods of making potato granules. Backfill refers to the operation of adding a single dried potato granule to a steamed flaky potato. The backfill method has higher requirements on the quality of raw potato materials and the quality of products is difficult to control. Large equipment is needed in backfill method, the cost is high but the production efficiency is higher and the output is considerable. 


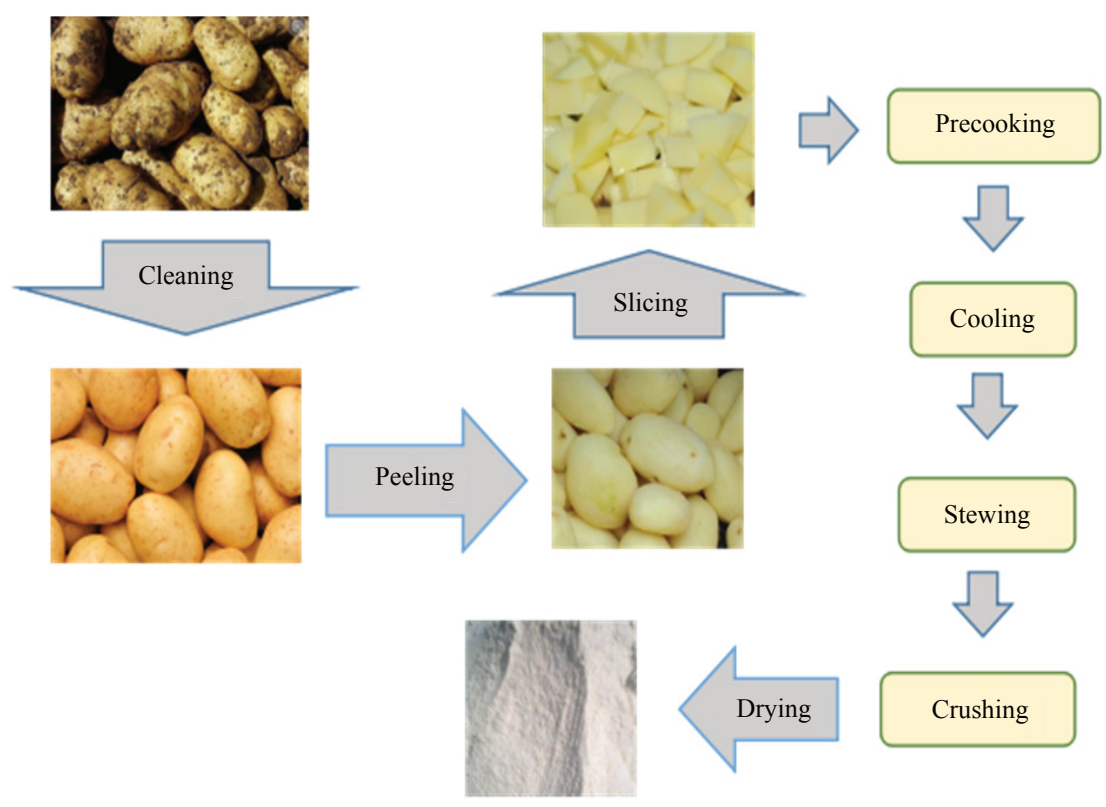

Fig. 1 Schematic role of potato flour by drying method

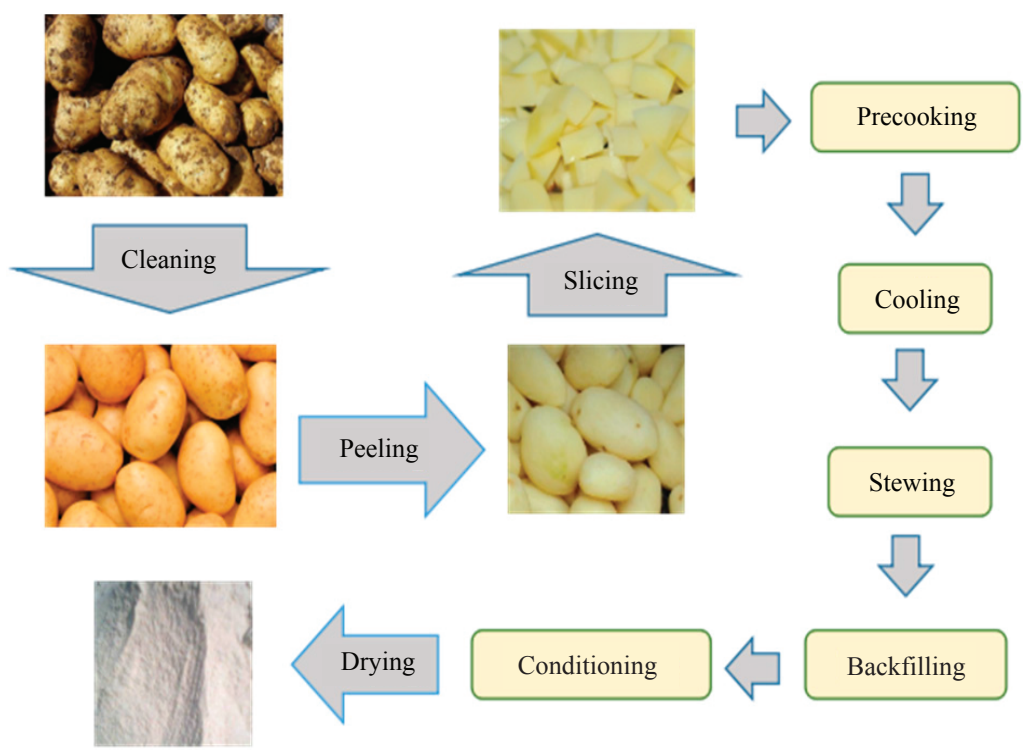

Fig. 2 Schematic role of potato flour by backfill method

In the whole preparation process, the mashed potatoes should be uniformly mixed with potato granules so that backfill particles can absorb excess water. Then the mixture of backfill should be mashed gently to minimize the cell damage rate. Drying temperature and time are adjusted according to the flow of materials during drying process ${ }^{[14-16]}$.

\subsection{Freeze-thaw Method Used in Preparations of Potato Granules}

Compared with backfill method, the advantage of freeze-thaw method is the simple equipment which is convenient for small-scale production and processing, and the product quality is easy to control. However, the freeze-thaw method could have a higher energy consumption and produce less output. As shown in Fig. 3, the freeze-thaw method is divided into two steps. The first step is to freeze raw potatoes at $-20{ }^{\circ} \mathrm{C}$ and $-40{ }^{\circ} \mathrm{C}$, the second step is to thaw it at $0{ }^{\circ} \mathrm{C}$ and $5{ }^{\circ} \mathrm{C}$. The hot air dryer is often used in pre-drying and drying process. The temperature and hot air flow rate should be controlled at $93{ }^{\circ} \mathrm{C}$ and $115 \mathrm{~m} / \mathrm{min}$ in the pre-drying process. The temperature and the hot air flow rate should be controlled at $85{ }^{\circ} \mathrm{C}$ and $90 \mathrm{~m} / \mathrm{min}$ in the drying process. The size of granulation particles is set to 100 mesh and the operation is performed in a pelletizer ${ }^{[14]}$. High moisture content in mashed potato flour after freezing and thawing means that the pre-drying process is carryied out before granulation is possible. 


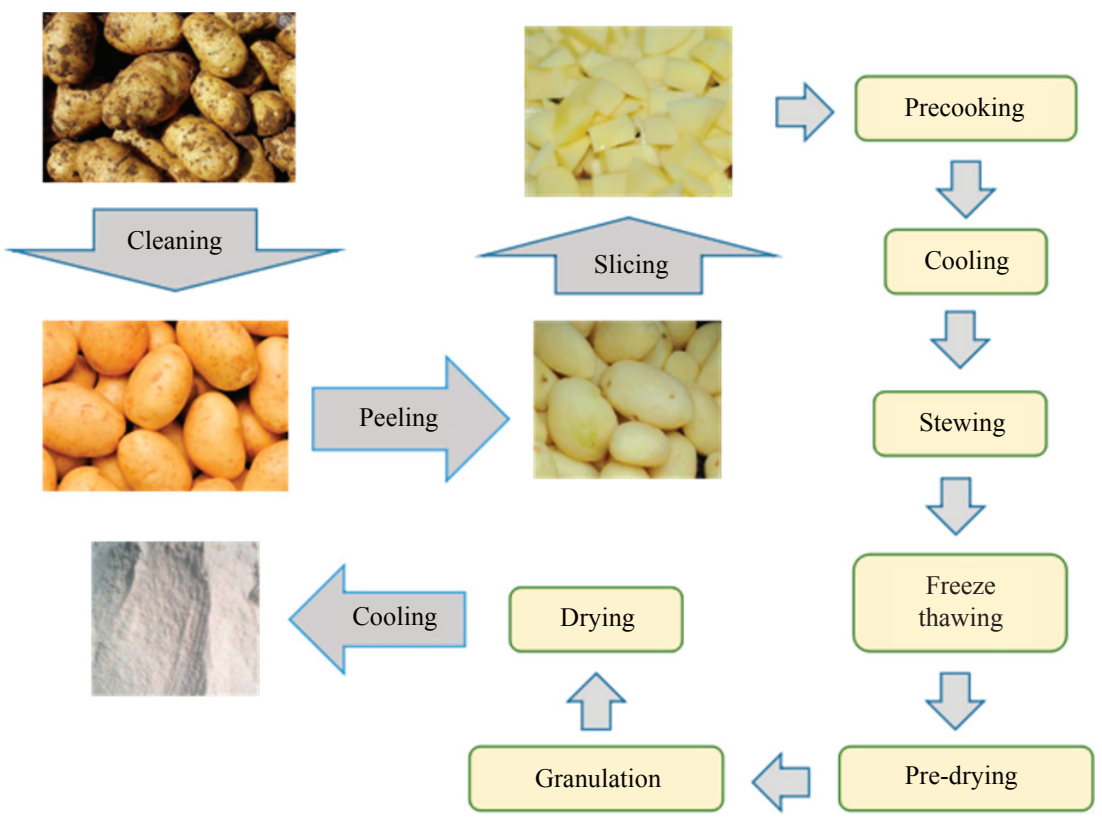

Fig. 3 Schematic role of potato flour by freeze-thaw method

\subsection{Analysis of Basic Process}

Potato flour preparation methods are different, but some basic processes are common, for example, cleaning $\rightarrow$ peeling $\rightarrow$ selecting $\rightarrow$ slicing and rinsing $\rightarrow$ precooking $\rightarrow$ cooling $\rightarrow$ stewing. The quality of potato flour could be improved by controlling the basic process.

\subsubsection{Cleaning}

The raw potatoes are cleaned in a washing machine. The small impurities on the potato's surface will be cleaned by the impact of water and the friction between raw materials. There are two types washer in this process, one is a horizontal washer and the other is a vertical washer. During the cleaning process, one washing machine or a combination of more washing machines can be used to improve potato quality.

\subsubsection{Peeling}

The cleaned potato raw materials are peeled before being made into flour. The steam peeling method is often used in order to ensure that the raw materials can be completely peeled. Raw materials are placed into a steam pipe and high-pressure steam is applied to the pipe to ripen the skin of the potatoes and then the pressure is quickly lowered which causes the cooked potato epidermis to crack and create gaps. Then the potato skin will be completely removed by a peeler.

\subsubsection{Selection}

The quality of potato flour is closely linked with the quality of raw materials. The peeled raw materials can be directly observed on the surface. Potatoes will germinate, turn black, become green and even rotten in the course of storage. In order to ensure the quality of the product, it is necessary to remove all the residual skin of the potatoes.

\subsubsection{Slicing and Rinsing}

Theoretically, to make the subsequent processing better, thickness of raw potataoes should be from 10 to $25 \mathrm{~mm}$, but in actual production, thickness of the slice mainly depends on the maturity of potatoes. The thinner potato, the better flavor. In the process of slicing, the contact surface of the blade and potatoes has a mechanical effect, some of the cells would be destroyed and the starch will leach out. The potato flakes need to be cleaned to remove the starch on the surface to ensure the preparation of whole potato flour, which needs a lower starch dissociation rate ${ }^{[17]}$.

\subsubsection{Precooking}

The reason that potatoes brown once peeled is that potatoes contain peroxidase and catalase. There are two main reasons for precooking. On the one hand, the browning of potatoes will affect the quality of final products. Precooking could inactivate some enzymes in the potatoes so as to prevent browning. On the other hand, precooking facilitates the separation of potato cells, which avoids increased temperature and helps the starch contained in potato gelatinize to protect cell membrane, therefore the force between cells is reduced. The pre-boiling water temperature that makes the starch gel is optimal, and the time of precooking is adjusted according to the thickness of the potatoes $^{[18]}$. Precooking also plays a role in sterilization to slow deterioration of the product.

\subsubsection{Cooling}

Plenty water is used to cool precooked flaked potatoes and the temperature is changed from hot to cold will enhance flexibility of cell wall. During cooling process, the starch from the surface of flaked potatoes will be removed to avoid caking during drying. The cooling will end only if the temperature in the middle of the flaked potatoes drops below $25^{\circ} \mathrm{C}$. 


\subsubsection{Cooking and Mashing}

After precooking and cooling, the flaked potatoes need to be cooked and cured to ensure a similar hardness as much as possible. Cooking time should be controlled between 20 and 50 min, cooking temperature between 85 and $100{ }^{\circ} \mathrm{C}$. Cooked flaked potatoes need to be mashed.

\subsection{Analysis of Key Processes}

\subsubsection{Virus-free Technology}

There is a bitter taste toxic steroidal alkaloid toxin, also named solanine in potatoes. It has $\alpha$-solanine and $\alpha$-canaline two forms. The $\alpha$-solanine is about $40 \%$, the remaining $60 \%$ is $\alpha$-solanine, and $\alpha$-canaline is more toxic and harmful ${ }^{[19]}$. Research has found that when the cumulative concentration of toxins reached $100 \mu \mathrm{mol} / \mathrm{L}$, it poses a threat to people ${ }^{[20]}$. Peeling, cooking and other processing technologies can effectively reduce toxic substances contained in fresh potatoes. This study showed that the content of $\alpha$-solanine and $\alpha$-carizidine in potato flour is significantly reduced compared with fresh potatoes ${ }^{[21]}$, and the peeled processed potato flour is better than non-peeled processed potato flour ${ }^{[22]}$.

\subsubsection{Color Protection Technology}

Fresh potatoes will change color after peeling, this phenomenon is known as browning. The browning is closely related to the quality of potato flour. Two types of discoloration occur in the peeled potatoes, gray-black and tan. Gray-black is enzymatic browning, while tan is non-enzymatic browning ${ }^{[23]}$. High-temperature steaming and adding color-retaining agent at room temperature is able to prevent browning. However, in the production and processing, in order to reduce capital investment, in most cases only color agent addition is utilized. In production, we should take cost, storage and transportation into account, so affordable and easy-to-get vitamin $\mathrm{C}$, citric acid, and phatic acid are used as color-protecting agents. In order to get the best color protection effect, materials can be soaked with vitamin $\mathrm{C}$ at a concentration of $8 \%$. In addition, the color-protecting effect of color-protecting agents combination is more significant than that of single color-protecting agent ${ }^{[24]}$.

\section{The Effect of Potato Flour on Flour Products}

Potato flour contains a lot of dry matters such as protein, cellulose, vitamins, minerals, and a small amount of fat and sugar, which is beneficial to human health ${ }^{[25]}$. It could be eaten directly or added to pasta products. Potato flour has a wider range of applications, the impact of flour products has also been widely concerned.

\subsection{Application in Steamed Bread}

China has a history of more than five thousand years, with a deep food culture including steamed bread which is a frequently and widely consumed product in China. The traditional steamed bread is a flour product, which is made of wheat flour, water and yeast ${ }^{[26]}$. Much attention is paid to processing of wheat flour, the nutrients in the flour are destroyed and the nutritional value is reduced ${ }^{[27]}$. The addition of potato flour could not only improve the taste of the steamed bread, but also improve its nutritive value.

Liu et al. ${ }^{[28]}$ found that the addition of potato granules in a range from 0 to $35 \%$ had a great influence on steamed bread quality. From the analysis of physicochemical properties, the water absorption of steamed bread is increased while specific volume is decreased. In addition, through the sensory evaluation, the quality of steamed bread is best after adding $20 \%$ potato flour. The results showed that the greater the amount of potato flour blended, the deeper the color of steamed bread would be, first white, then yellow and then dark, and the inner texture would become thicker. Therefore, the taste would be impaired and the quality would be lower ${ }^{[29]}$. This may because potato flour contains a certain amount of starch, which makes it unable to form gluten network and the addition of potato flour results in dilution of the original gluten protein in wheat flour $^{[30]}$. The decrease of gluten protein content of potato steamed bread causes various problems. If the fermentation time is prolonged, it becomes difficult to shape and form the dough during processing, and the bread cracks easily after steaming. The potato development team of the Chinese Academy of Agricultural Sciences has solved these problems ${ }^{[31]}$.

\subsection{Application in Bread}

A proper amount of potato flour in bread enriches the variety of bread and at the same time increases the nutrients, and changes the flavor. Zhang et al. ${ }^{[32]}$ found that an increase in potato flour increased water content of the finished bread, while the acidity of bread would not be greatly affected. When the percentage of potato flour was controlled from $5 \%$ to $15 \%$, the volume of bread was not affected. When the percentatge of potato flour was over $15 \%$, the specific volume of bread was affected, and its value decreased with the increasing potato flour. The optimum amount of potato flour could make the bread elastic, soft and tasty. The flavor of potato and bread is well blended and very attractive. In order to make bread with the best quality, Liu et al. ${ }^{[33]}$ constantly adjusted the potato flour content. It was concluded that when the content of all potato flour was $20 \%$, the quality of the bread was the best. Curti et al. ${ }^{[34]}$ found that the best quality bread needed $15 \%$ potato flour. Currently, there is no unified view and further research is needed. The mixture of flour and potato flour in a suitable proportion could also slow down the aging of bread and prolong its shelf life ${ }^{[32]}$.

\subsection{Application in Noodles}

Noodles have more than four thousand years history in China. With the rapid development of economy, people have begun to pursue a higher quality of life. Potato noodles contain a lot of nutrients, such as the proteins, vitamins and cellulose needed by the human body, which is in line with people's nutritional, functional and health-care needs, at the same time increasing the diversity of noodles and improving the freshness of the diet.

Lakra et al. ${ }^{[35]}$ blended potato flour and wheat flour to make the fresh noodles. This practice gives good cooking 
quality and texture characteristics to the noodles, while also imparting the potato flavor; Fu et al. ${ }^{[36]}$ changed the proportion of potato flour in making potato noodles, recorded and analyzed the physicochemical properties and quality of noodles. The results showed that the value of water absorption and cooking loss of noodles increased with the addition of potato flour. The addition of potato flour enhanced the taste and flavor of the noodles. When the total amount of potato flour was $35 \%$, the noodles were of the highest quality ${ }^{[37]}$.

\section{Preparation of Potato Flour}

Potato flour is a granular, chip like or powdery product produced by a series of dehydration and drying processing of raw potatoes. Potato flour not only includes the basic nutritional components, but also some functional factors such as anthocyanin, dehydroepi, rosterone, and mucus proteins, so its effect on health care is significant ${ }^{[4]}$. The basic production process is as follows: potato $\rightarrow$ cleaning $\rightarrow$ peeling $\rightarrow$ slicing up $\rightarrow$ color protecting $\rightarrow$ stewing $\rightarrow$ drying $\rightarrow$ crushing $\rightarrow$ screening $\rightarrow$ finished product. At present, the potato flour preparation technology and equipment is relatively mature.

\section{The Effect of Potato Flour on the Flour Products}

\subsection{Application in Steamed Bread}

The quality of steamed bread made by adding potato flour to wheat flour is significantly different in quality from that of the steamed bread made by traditional wheat flour. This study reveals that elasticity, viscosity and recovery of steamed bread are closely related to the addition of potato flour. Adding certain percentage of potato flour would reduce the elasticity, viscosity and recovery. The viscosity gradually increases from 5\% to $30 \%$, other indicators in this range change irregularly. The hardness and chewiness of steamed bread increase significantly with the addition of sweet potato flour, while the specific volume of steamed bread decrease, the color gets darker, and the score of sensory evaluation gets less ${ }^{[38]}$.

\subsection{Application in Bread}

Adding some potato flour to making bread could not only improve the nutritional value, but also reduce the deterioration rate of bread, and the storage time would be prolonged. The experimental data showed that the volume and acidity of bread made by adding 4\%-12\% potato flour was not significantly different. When the proportion of potato flour exceeded $12 \%$, the specific volume of bread was affected by the total amount of potato flour due to the increase of potato flour addition ${ }^{[39]}$.

\subsection{Application in Noodles}

The addition of potato flour to noodles, the rheological properties and quality of the noodles would also be susceptible to change. In order to measure the changes of noodle quality, evaluation standards of noodles are ripening rate, cooking loss rate and bending break rate. The results showed that with the increase of potato flour proportion, the three values gradually increased with different trends; the addition amount is between
$5 \%$ and $10 \%$, the three values remained at a low level, the noodles were good with better chewiness and suitable viscosity. This maybe because when there was too much potato flour addition displaced the wheat flour, the amount of gluten in the noodles decreased, the strength of the noodles decreased, the quality of the noodles changed, and the noodles broke easily ${ }^{[40]}$.

\section{Conclusions}

With the development of potatoes as a staple food, people have paid more and more attention to it and its related products. Potato whole flour can be directly eaten as a re-hydrated food, can be also blended with other daily food. It has a wide range of applications in life. It contains a large number of nutrients that are good for health. It is suitable for people of all ages, and the market prospect is very optimistic. Therefore, it has great research value. The cultivation area and the yield of potatoes in China are at the fore front of the world. Although the potato resources are very rich, the development of potato industry is still at the early stage, the future development is very optimistic and the potentiality is beyond predictions. The future research direction should be focused on optimizing processing technologies of potato flour and related production equipment, especially on the research of potatoes, which needs more manpower and material resources. While improving products quality, lower production cost to expand the application fields of potato flour.

\section{Conflict of Interest}

The authors declare that there is no conflict of interest.

\section{Acknowledgments}

The authors would like to thank National Engineering Laboratory for Wheat and Corn Further Processing for providing laboratory facilities to carry out the study, and Henan Academy of Agricultutal Sciences for authenticating the wheat samples.

\section{References}

[1] MISRA A, KULSHRESTHA K. Effect of storage on nutritional value of potato flour made from three potato varieties[J]. Plant Foods for Human Nutrition, 2003, 58(3): 1-10.

[2] BORDOLOI A, KAUR L, SINGH J. Parenchyma cell microstructure and textural characteristics of row and cooked potatoes[J]. Food Chemistry, 2012, 133(4): 1092-1100.

[3] ŠIMKOVÁ D, LACHMAN J, HAMOUZ K, et al. Effect of cultivar, location and year on total starch, amylose, phosphorus content and starch grain size of high starch potato cultivars for food and industrial processing[J]. Food Chemistry, 2013, 141(4): 3872-3880.

[4] ZHANG Z, WHEATLEY C C, CORKE H. Biochemical changes during storage of sweet potato roots differing in dry matter content[J]. Postharvest Biology and Technology, 2002, 24(3): 317-325.

[5] SUN P, ZHOU Q Z, GAO J, et al. Color protecting of potato granules[J]. Food Research and Development, 2010, 31(10): 43-66.

[6] SINGH J, SINGH N, SHARMA T R, et al. Physicochemical, rheological and cookie making properties of corn and potato flours[J]. Food Chemistry, 2003, 83(3): 387-393.

[7] ZHANG Z, WANG J, ZHANG X, et al. Effects of radio frequency assisted blanching on polyphenol oxidase, weight loss, texture, color and microstructure of potato[J]. Food Chemistry, 2018, 248: 173-182. 
[8] SANDHU K S,SHARMA L, KAUR M. Effect of granule size on physicochemical, morphological, thermal and pasting properties of native and 2-octenyll-ylsucci-nylated potato starch prepared by dry heating under different $\mathrm{pH}$ conditions[J]. LWT-Food Science and Technology, 2015, 61(1): 224-230.

[9] ISELA C P, MU T, ZHANG M,et al. Effect of high hydrostatic pressure to sweet potato flour on dough properties and characteristics of sweet potato-wheat bread[J]. International Journal of Food Science and Technology, 2018, 53(4): 1087-1094

[10] RADY A M, SOLIMAN S N, E-WERSH A. Effect of mechanical treatments on creep behavior of potato tubers[J]. Engineering in Agriculture, Environment and Food, 2017, 10(4): 282-291.

[11] CARILLO P, CACACE D, PASCALE S D, et al. Organic vs. traditional potato powder[J]. Food Chemistry, 2012, 133(4): 1264-1273.

[12] JIN C, XU D, ZENG F, et al. A Simple method to prepare raw dehydrated potato flour by low-temperature vacuum drying $[\mathrm{J}]$ International Journal of Food Engineering, 2017, 13(11): 20170127(1-10).

[13] KANG J, LEE J, CHOI M, et al. Physicochemical and textural properties of noodles prepared from different potato varieties[J]. Preventive Nutrition and Food Science, 2017, 22(3): 246-250.

[14] RUHANIAN S, MOVAGHAMEJAD K. Mathematical modeling and experimental analysis of potato thin-layer drying in an infrared-convective dryer[J]. Engineering in Agriculture, Environment and Food, 2016, 9(1): 84-91.

[15] FRIEDMAN M. Potato glycoalkaloids and metabolites: roles in the plant and in the diet[J]. Journal of Agricultural and Food Chemistry, 2006, 54(23): 8655-8681.

[16] WANG Q, CAO Y, ZHOU L, et al. Effects of postharvest curing treatment on flesh colour and phenolic metabolism in fresh-cut potato products[J]. Food Chemistry, 2015, 169: 246-254.

[17] HOWARD P H. AFHVS 2016 presidential address: decoding diversity in the food system:wheat and bread in North America[J]. Agriculture and Human Values, 2016, 33(4): 953-960.

[18] RAHAIE S, GHARIBZAHEDI S M T, RAZAVI S H, et al. Recent developments on new formulations based on nutrient-dense ingredients for the production of healthy-functional bread:a review[J]. Journal of Food Science and Technology, 2014, 51(11): 2896-2906.

[19] KIM E J, KIM H S. Influence of pectinase treatment on the physicochemical properties of potato flours[J]. Food Chemistry, 2015, 167(15): 425-432.

[20] FRIEDMAN M, KOZUKUE N, KIM H, et al. Glycoalkaloid, phenolic, and flavonoid content and antioxidative activities of conventional nonorganic and organic potato peel powders from commercial gold, red, and Russet potatoes[J]. Journal of Food Composition and Analysis, 2017, 62: 69-75.

[21] ELZBIETA R. The effect of industrial potato processing on the concentrations of glycoalkaloids and nitrates in potato granules[J] Food Control, 2012, 28(2): 380-384.

[22] TAJNER-CZOPEK A, RYTELE, KIA A, et al. The influence of thermal process of coloured potatoes on the content of glycoalkaloids in the potato products[J]. Food Chemistry, 2012, 133(4): 1117-1122.

[23] AKISSOE N, HOUNHOUIGAN J, MESTRES C, et al How blanching and drying affect the colour and functional characteristics of yam ldioscorea cay enensis-rotundata flour[J].
Food Chemistry, 2003, 82(2): 257-264.

[24] PAN F, YANG Q X, LIANG G E, et al. Research of production technology of potato starch[J]. Food Research and Development, 2009, 30(7): 92-95.

[25] NIELSEN G G B, KJÆR A, KLÖSGEN B, et al. Dielectric spectroscopy for evaluating dry matter content of potato tubers [J]. Journal of Food Engineering, 2016, 189: 9-16.

[26] YADAV A R, GUHA M, THARANATHAN R N, et al. Influence of drying conditions on functional properties of potato flour[J]. European Food Research and Technology, 2006, 223(4): 553-560.

[27] JEONG Y, JANG Y, CHANG Y H, et al. Prediction of consumer acceptability of potato chips with various moisture contents using survival analysis[J]. Food Science and Biotechnology, 2013, 22(6): 1621-1627.

[28] LIU X I, MU T H, SUN H N, et al. Influence of potato flour on dough rheological properties and quality of steamed bread[J]. Journal of Integrative Agriculture, 2016, 15(11): 2666-2676.

[29] SANDHU K S, KAUR M, MUKESH. Studies on noodle quality of potato and rice starches and their blends in relation to their physicochemical, pasting and gel textural properties[J]. LWT Food Science and Technology, 2010, 43(8): 1289-1293.

[30] ZHU F. Staling of Chinese steamed bread: quantification and control[J]. Trends in Food Science and Technology, 2016, 35: 118-127.

[31] LIU X, MU T, SUN H. Influence of different hydrocolloids on dough thermo-mechanical properties and in vitro starch digestibility of gluten-free steamed bread based on potato flour[J] Food Chemistry, 2018, 239: 1064-1074.

[32] ZHANG H, XU F, WU Y, et al. Progress of potato staple food research and industry development in China[J]. Journal of Integrative Agriculture, 2017, 16(12): 2924-2932.

[33] LIU X, MU T, YAMUL K D, et al. Evaluation of different hydrocolloids to improve doughrheological properties and bread quality of potato-wheat flour[J]. Jouranl Food Science Technolgy, 2017, 54(6): 1597-1607.

[34] CURTI E, CARINI E, DIANTOM A, et al. The use of potato fibre to improve bread physico-chemical properties during storage $[\mathrm{J}]$. Food Chemistry, 2016, 195: 64-70.

[35] LAKRA P, SEHGAL S. Influence of processing on total and extractable mineral content of products prepared from potato flour[J]. Journal of Food Science and Technology-mysore, 2011, 48(6): 735-739.

[36] FU B X. Asian noodles: history, classification, raw materials, and processing[J]. Food Research International, 2008, 41: 888-902.

[37] XU F, HU H, DAI X, et al. Nutritional compositions of various potato noodles: comparative analysis[J]. International Journal of Agricultural and Biological Engineering, 2017, 10(1): 218-225.

[38] LIU X, MU T, SUN H, et al. Influence of different hydrocolloids on dough thermo-mechanical properties and in vitro starch digestibility of gluten-free steamed bread based on potato flour[J]. Food Chemistry, 2018, 239: 1064-1074.

[39] WANG L, GUO J, WANG R, et al. Studies on quality of potato flour blends with rice flour for making extruded noodles[J]. Cereal Chemistry, 2016, 93(6): 593-598.

[40] PU H, WEI J, WANG L, et al. Effects of potato/wheat flours ratio on mixing properties of dough and quality of noodles[J]. Journal of Cereal Science, 2017, 76: 236-242. 